\title{
Assessment of water quality bounamoussa river in el tarf region using water quality index (Algeria)
}

\begin{abstract}
Water quality is an important standard in matching water require and contribute. Abundant degree of freshwater is prominent for biological requirements and is a vital surface of incorporated environmental managing and sustainable development. The quality of water indices evaluation enterprise particular value which reduce the immense quantity of parameters and simply characterize data. The aim objective of the present study is to assess the suitability of surface water of Bounamoussa River situated in El-Tarf city located in the Algerian's extreme northeast, for drinking purpose based on calculated water quality index standards. Per methodology, WQI is a significant parameter to check the quality of water, and its calculation was carried out by using relations given in the water quality index computation which twelve selected parameters $\left(\mathrm{pH}, \mathrm{EC}, \mathrm{TH}, \mathrm{Ca}, \mathrm{Mg}, \mathrm{Na}, \mathrm{K}, \mathrm{Cl}, \mathrm{NH}_{4}\right.$, $\mathrm{SO}_{4}, \mathrm{NO}_{2}, \mathrm{NO}_{3}$ ) have been considered, which were measured at nine stations along the river during two sampling campaigns (winter and summer seasons). The results showed that the computed WQI values of Bounamoussa River surface water extend from 32,80 to 65,77 with an average 46,76 in winter and fluctuate from 35,86 to 97,46 with an average of 47,25 in summer, in general, the study region in both seasons is under excellent to good category. Water from almost all the sampled sites can be careful as suitable for drinking purposes. It's recommended to continue monitoring the water of this ecosystem to facilitate the establishment at all levels to supervise and defend the natural resources of the region.
\end{abstract}

\author{
Volume 4 Issue 6 - 2020 \\ Lilia Zaoui ${ }^{1,2}$ \\ 'Department of Pharmacy, Faculty of Medicine, University MBB \\ Batna 2, Batna, Algeria \\ ${ }^{2}$ Laboratory Research of Soil and Sustainable Development, \\ Department of Biology, Faculty of Sciences, Badji Mokhtar \\ University, Annaba, Algeria
}

Correspondence: Lilia Zaoui, Department of Pharmacy, Faculty of Medicine, University MBB Batna 2, Batna,Algeria, Email l.zaoui@univ-batna2.dz

Received: November 07, 2020 | Published: December 31, 2020

Keywords: surface water quality, drinking purpose, water scale, seasons, suitability

\section{Introduction}

A great amount of nations, favour the WQI method to assess general river status, because of being single appreciated and easy to comprehend. ${ }^{1-5}$ WQI is one of the main helpful kits to supply advice on the quality of water to the strategy makers and environmentalists. ${ }^{6}$ In effect, natural procedures such as temperature and rainfall along with anthropogenic aspects that disturb the river water quality and steer to different characteristics between periods. ${ }^{7}$ Opinion obtainable that irrigation accounts for approximately 70 percent of thz water with drawl across the world and consumptive water use being about 90 percent. Accordingly, precipitation flood is more probable to happen in an urban areas while snow transport lowers the degree of snow thaw overflow. ${ }^{8}$ The nature of surface water is a delicate issue and it is an incredible ecological concern around the world. It is critical for long-term economic development, social welfare, and environmental sustainability. Some physicochemical parameters, some hydrogeochemical parameters calculated from the water quality parameters and a few graphical representations determine the suitability of the river water for agricultural use. ${ }^{9,10}$ Horton $^{11}$ was the most researchers who proposed the profit of using the WQI and later, many studies concerning water index have been describe daway for the diverse marine system. Later on, Peace et al. ${ }^{12}$ also proposed a WQI process that used by numerous scientists such as Weight Arithmetic Water Quality Index. ${ }^{13-19}$ These indexes have been useful for assessment of water quality in a specific region. ${ }^{20-22}$ These indices degree the quality of water from its basins due to the issues that affect them. Thus, Inclusive River water quality assessing is a helpful device not only to evaluate the suitability of surface water for irrigation, but also to verify an effective administration of water resources and the safety of aqua systems. ${ }^{5,22,23}$ The main objective of the current research is to examine the suitability of Bounamoussa River surface water for drinking purposes based on calculated water quality index values in dissimilar seasons and at a diverse segment of the River.

\section{Materiel and methods}

\section{Characteristics of the research area}

Bounamoussa river across El-Tarf city is located in the Algerian's extreme northeast and prolonged on a space of $2.891 .63 \mathrm{Km}^{2}$. It has a $90 \mathrm{~km}$ of coastline (Figure 1). This river is contained in El-Tarf and Annaba municipalities, which $90 \%$ restricted in El-Tarf city with its communities of Besbes, Echatt, Zerizer, Asfour, Ben M'Hidi, and Chebaita Mokhtar and the $10 \%$ for Annaba city reserved at both communities El-Hadjar, El-Bouni only. ${ }^{25}$ the focal sources of employment are agriculture, cultivation, and animals, most of them perform required labor, though the other sectors are the food industry primarily tomatoes and oranges, wheat factories, stone squashing. The study area subjected to a Mediterranean climate characterized by two dissimilar periods: one rainy, marked by high precipitation and low temperatures from October to May, and other dry and warm with high temperatures arriving their highest in August with low precipitation. Usual southerly winds upset off the sea through the winter; and in summer, the hot Sirocco blows in a south-south-westerly way, resounding with it a freshening effect that strongly felt during a onemonth of period. ${ }^{26}$ The contextual research will concern Bounamoussa River, which is utilized for drinking propose. The water from the dam presents appropriate quality for irrigation.

\section{Sampling stations}

Water sample collection was made for two periods, summer and winter from nine (09) sites selected stations El Tarf City drained by Bounamoussa River. The sampling sites listed found on stable space, with minor deviance relying on the geographic condition and easy access. The water samples collected physically from a depth of $20 \mathrm{~cm}$ from the surface of the water, especially where the course of water was high, to acquire great homogenized samples. Plastic holders of volume greater than $1500 \mathrm{~cm}^{3}$ utilized for the sampling of each sample 
in every site and gathered for this research. Sampling, conservation, and transfer of samples to the research laboratory were performed per standard procedures, Rodier ${ }^{27}$ and with the procedures delineated in the standard methods described by Motsara et al. ${ }^{28}$ and APHA ${ }^{29}$ which index scores were determined for twelve selected parameters (Table 1). Their average values are compared with standards of potable water quality suggested by the World Health Organization $\mathrm{WHO}^{30}$ and used to assess WQI.

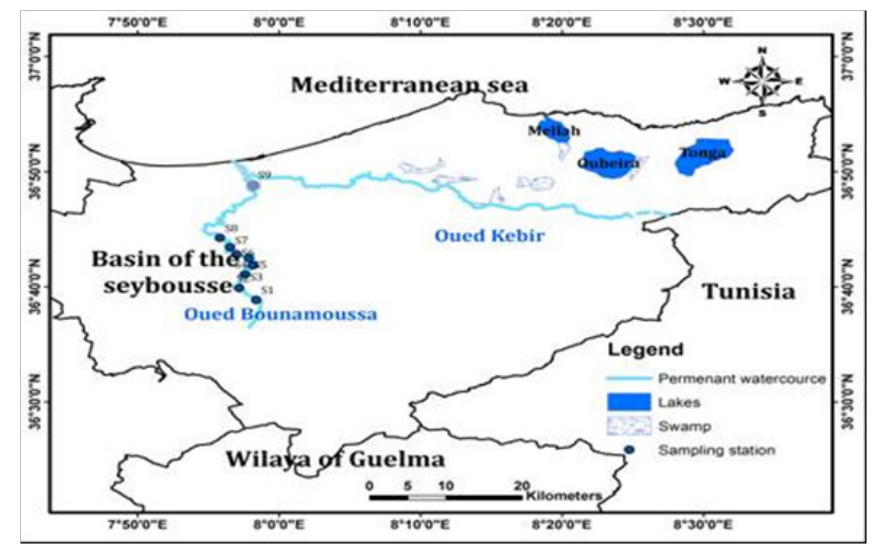

Figure I Map of study area location.

\section{WOI calculation}

WQI is an effective tool that represents the general water quality at a certain place and time based on physicochemical parameters. In the present study, the water quality index (WQI) has been applied to assess the suitability of surface water quality of the Bounamoussa River for drinking purposes. For this purpose twelve parameters have been selected which are:

The calculation and formulation of the WQI involved the following steps:

The first step to calculate the water quality index is to set specific weights for chemical parameters and their relative importance in drinking water, as shown in Table $1 .^{31}$ The highest weight was given to every parameter due to the importance of the role played in water quality than others.

Table I Methods used for the chemical analysis of surface water

\begin{tabular}{ll}
\hline Chemicals variables & Methods used \\
\hline $\mathrm{pH}$ & Digital $\mathrm{pH}$-meter \\
Electrical Conductivity, $\mathrm{EC}(\mu \mathrm{S} / \mathrm{cm})$ & EC-meter \\
Calcium, $\mathrm{Ca}++(\mathrm{mg} / \mathrm{l})$ & Titration with EDTA \\
Magnesium, $\mathrm{Mg}++(\mathrm{mg} / \mathrm{l})$ & Titration with EDTA \\
Total Hardness, $\mathrm{TH}(\mathrm{mg} / \mathrm{l})$ & Titration with EDTA \\
Sodium, $\mathrm{Na}+(\mathrm{mg} / \mathrm{l})$ & Flame photometric method \\
Potassium, $\mathrm{K}+(\mathrm{mg} / \mathrm{l})$ & Flame photometric method \\
Ammonia, $\mathrm{NH} 4+(\mathrm{mg} / \mathrm{l})$ & Spectrophotometric method \\
Chlorides, $\mathrm{Cl}-(\mathrm{mg} / \mathrm{l})$ & Titration with AgNO3 \\
Sulphate, $\mathrm{SO}_{4}-(\mathrm{mg} / \mathrm{l})$ & Spectrophotometric method \\
Nitrate, $\mathrm{NO}_{3}-(\mathrm{mg} / \mathrm{l})$ & Spectrophotometric method \\
Nitrite, $\mathrm{NO}_{2}-(\mathrm{mg} / \mathrm{l})$ & Spectrophotometric method \\
\hline
\end{tabular}

The relative weight ( $\mathrm{Wi}$ ) is calculated using the equation number one given below:

$$
\mathrm{Wi}=\mathrm{Wi} / \sum_{\mathrm{i}-1}^{\mathrm{n}} \mathrm{Wi}
$$

Where, Wi relative weight, wi the weight of every parameter, and $\mathrm{n}$ is the number of parameters

$$
\begin{gathered}
\mathrm{qi}=\left(\frac{\mathrm{Ci}}{\mathrm{Si}}\right) * 100 \\
\mathrm{SI}=\mathrm{Wi}^{*} \mathrm{qi} \\
\mathrm{WQI}=\sum \mathrm{SIi}
\end{gathered}
$$

The calculated WQI values are classified into five classes to choose the water quality status (WQS) as shown in Table 3.

\section{Results}

Applying the previous calculations on the results of water assessment data of the Bounamoussa River, in both seasons WQI for all samples have been designed in Table 2, 3 and 4. In this study, the profiles of the obtained results exposed that, for the winter season, the calculated WQI values varied from 32,80 to 65,77 with an average 46,76 , however it oscillates from 35,86 to 97,46 with an average value of 47,25 in summer. In accord to Yadav et al..$^{32}$ and to the water quality index values were categorized into five varieties as presented in Table 3. When relating the results of the computed water quality index with the Ramakrishnalah classification; it shows that $33 \%$ of the water samples collected from downstream of the river falls in the second category (II) and $67 \%$ of the water samples falls in the first category (I) in winter. While, in summer, it designates that $11 \%$ of the water samples fall in the second category (II) and $89 \%$ of the water samples falls in the first category (I). The general water quality status during the period of study refer to excellent water quality. However, allowing to Yadav classification, in the rainy period, $67 \%$ of the water samples falls in the second category (II) which mentions the good quality and $33 \%$ of the water samples falls in the third category (III) that signifies poor quality. Although, in the dry period, it designates that $11 \%$ of the water samples falls in the third category (III) and $89 \%$ of the water samples falls in the second category (II).

Table 2 Suggested Standards for drinking water quality and evaluated unit weights of specific parameters

\begin{tabular}{llll}
\hline Variables & $\begin{array}{l}\text { Standards } \\
(\mathbf{S I})\end{array}$ & $\begin{array}{l}\text { Weight } \\
\text { (wi) }\end{array}$ & Relative weight (Wi) \\
\hline $\mathrm{pH}$ & 6,5 & 2 & 0,045 \\
$\mathrm{EC}(\mu \mathrm{S} / \mathrm{cm})$ & 300 & 5 & 0,114 \\
$\mathrm{Ca}++(\mathrm{mg} / \mathrm{l})$ & 75 & 2 & 0,045 \\
$\mathrm{Mg}++(\mathrm{mg} / \mathrm{l})$ & 50 & 2 & 0,045 \\
$\mathrm{TH}(\mathrm{mg} / \mathrm{l})$ & 300 & 2 & 0,045 \\
$\mathrm{Na}+(\mathrm{mg} / \mathrm{l})$ & 200 & 2 & 0,045 \\
$\mathrm{~K}+(\mathrm{mg} / \mathrm{l})$ & 12 & 3 & 0,068 \\
$\mathrm{NH} 4+(\mathrm{mg} / \mathrm{l})$ & 0,5 & 5 & 0,114 \\
$\mathrm{Cl}-(\mathrm{mg} / \mathrm{l})$ & 250 & 3 & 0,068 \\
$\mathrm{SO}_{4}^{-}(\mathrm{mg} / \mathrm{l})$ & 200 & 4 & 0,091 \\
$\mathrm{NO}_{3}-(\mathrm{mg} / \mathrm{l})$ & 45 & 5 & 0,114 \\
$\mathrm{NO}_{-}-(\mathrm{mg} / \mathrm{l})$ & $0, \mathrm{I}$ & 5 & 0,114 \\
& & $\sum \mathrm{wi}=40$ & $\sum \mathrm{Wi}=1,000$ \\
\hline
\end{tabular}


Table 3 Classification of Surface water quality according to WQI range

\begin{tabular}{llll}
\hline Category & Water Quality & WQI Yadav et al. ${ }^{32}$ & WOI Ramakrichnaiah et al. ${ }^{2}$ \\
\hline I & Excellent & $0-25$ & $<50$ \\
II & Good & $26-50$ & $50-100$ \\
III & Poor & $5 I-75$ & $100-200$ \\
IV & Very Poor & $76-100$ & $200-300$ \\
V & Unsuitable & Above 100 & $>300$ \\
\hline
\end{tabular}

Table 4 Water quality indices and water quality status at sampling sites during both seasons

\begin{tabular}{|c|c|c|c|c|c|c|}
\hline \multicolumn{4}{|c|}{ Winter } & \multicolumn{3}{|c|}{ Summer } \\
\hline \multicolumn{7}{|c|}{ Water quality based on the scale suggested by } \\
\hline Sites & WQI & Yadav et al. ${ }^{32}$ & Ramakrichnaiah et al. ${ }^{2}$ & WOI & Yadav et al. ${ }^{32}$ & Ramakrichnaiah et al. ${ }^{2}$ \\
\hline SI & 39,04 & Good & Excellent & 36,76 & Good & Excellent \\
\hline S2 & 34,51 & Good & Excellent & 43,00 & Good & Excellent \\
\hline S3 & 32,80 & Good & Excellent & 35,86 & Good & Excellent \\
\hline S4 & 39,10 & Good & Excellent & 43,53 & Good & Excellent \\
\hline S5 & 43,23 & Good & Excellent & 37,40 & Good & Excellent \\
\hline S6 & 58,52 & Poor & Good & 46,85 & Good & Excellent \\
\hline S7 & 58,04 & Poor & Good & 44,90 & Good & Excellent \\
\hline S8 & 49,82 & Good & Excellent & 39,45 & Good & Excellent \\
\hline S9 & 65,77 & Poor & Good & 97,46 & Poor & Good \\
\hline
\end{tabular}

\section{Discussion}

Estimation of drinking water quality is a suitable condition among emerging community health problems in this background where accessibility of secure water is at danger unpaid to normal and manmade actions. This cross-sectional research conducted across the study region was expected to measure drinking water quality using WQI which delivered posts on the complex consequence of chemical parameters on water. ${ }^{33}$ The general water quality status through both seasons of study refer to good water quality for drinking purpose, excluding at sites S6, S7 and S9 through the wet season, and S9 also during the dry season, which was classified as "poor" water quality and inappropriate for drinking usages as recommended by Brown as per the classification given in Table $3 .{ }^{34}$ The capacity is because of severe execution of pollution management rules and regulations on water value for industries and previous commercial sectors and/or the preamble of a few corrective processes engaged by the Bounamoussa River management side. ${ }^{6}$ The unsuitability of these water samplings in some sites could be because of the interaction of rainwater with the sedimentary rock in the region leading to the disbanding of ions into the aquifer or could because of different anthropogenic actions, for example, dirt dumping, unused disposal, agricultural actions, the presence of unclean drainage behind the water source, and anthropogenic contamination from the close dump location. Still, these three locations with poor water quality could be appropriate for drinking water uses succeeding a basic decontamination action, such as filtration. Cyclical as well as location-wise difference of index values can be because of distinction in physicochemical attributes of surface water. ${ }^{35,36}$ These results were found to be in accordance with other studies such as, ${ }^{6,37}$ which use the similar WQI method (Weighted arithmetic Water Quality Index). ${ }^{38,39}$

\section{Conclusion}

On the origin of the study carried out in this research, it can be resolved that significant differences in WQI values detected over the periods and across positions with the maximum WQI values (poor quality) in summer on downstream of the River, while the lowest values (better quality) were in winter on upstream of River. The results presented in this paper are based on selected water quality parameters determined in the Bounamoussa River system during the summer and winter season shows the values of WQI increased from more than 30 to almost 65 then to 97 and water quality was better in winter compared to that in summer. Based on these data, the water quality conditions in the Bounamoussa River system are analyzed. Information set issued to estimate a WQI to give an inclusive knowledge of the water quality of the studied area. Generally, the study area in both seasons is under excellent to good category. It's recommended to continue monitoring the water of this ecosystem to facilitate the establishment at all levels to supervise and defend the natural resources of the region. The performance of the character methodologies in a tolerable number of water bodies considered by diverse hydrological and climatic conditions is essential before applying them on a large level.

\section{Acknowledgments}

We are thankful to the laboratory team for providing the necessary facilities and their help during laboratory analysis.

\section{Conflicts of interest}

\section{None.}




\section{References}

1. Mohamed I, Othman F, Ibrahim AI, et al. Assessment of water quality parameters using multivariate analysis for Klang River basin, Malaysia. Environmental monitoring and assessment. 2015;(187):4182.

2. Moyel MS, Hussain NA. Water quality assessment of the Shatt al-Arab River, Southern Iraq. Journal of Coast Life Medicine, 2015;3(6):459465.

3. Alexakis D, Tsihrintzis VA, Tsakiris G, et al. Suitability of Water Quality Indices for application in lakes in the Mediterranean. Water Resources Management. 2016;30(5):1621-1633.

4. Mitra P, Reddy PB. Application of Water Quality Index (WQI) as a tool for assessment of pollution status of Shivna River at Mandsaur, MP India. Trends in Life Science. 2016;(5):4-11.

5. Shil S, Singh UK, Menta P. Water quality assessment of a tropical river using water quality index (WQI), multivariate statistical techniques and GIS. Applied Water Science. 2019;(9):168.

6. Naubi I, Zardari NH, Shirazi SM, et al. Effectiveness of Water Quality Index for Monitoring Malaysian River Water Quality. Pol. J. Environ. Stud. 2016;25(1):10.

7. Iqbal K, Ahmad S, Dutta V. Pollution mapping in the urban segment of a tropical river: is water quality index (WQI) enough for a nutrientpolluted river? Applied Water Science. 2019;(9):197.

8. Garcia CAB, Garcia H L, Mendonça MCS, et al. Assessment of water quality using principal component analysis: a case study of the açude da Macela-Sergipe-Brazil. Water resources. 2017;(7): 8.

9. Bahroun S, Chaib W, Halimi S. Suitability of Cheffia dam surface waters for irrigation (E1 Tarf area). Journal of Biodiversity and Environmental Sciences (JBES). 2017;(10):274-282

10. Zaoui L, Kahit FZ, Benslama M. Assessment of irrigational quality of surfce waters in El Tarf area, Algeria. Journal of Fundamental and Applied sciences, 2019;(11):1244-1255.

11. Horton RK. An index number system for rating water quality. Journal of Water Pollution Control Federation. 1965;(37):300-306.

12. Pesce SF, Wunderlin DA. Use of water quality indices to verify the impact of Córdoba City (Argentina) on Suquía River. Water research. 2000;(34):2915-2926.

13. Kangabam RD, Bhoominathan SD, Kanagaraj S, et al. Development of a water quality index (WQI) for the Loktak Lake in India. Appl Water Sci. 2017;(7):2907-2918.

14. Misaghi F, Delgosha F, Razzaghmanesh M, et al. Introducing a water quality index for assessing water for irrigation purposes: A case study of the Ghezel Ozan River. Science of the Total Environment. 2017;(589):107-116

15. Zeinalzadeh K, Rezaei E. Determining spatial and temporal changes of surface water quality using principal component analysis. Journal of Hydrology: Regional Studies. 2017;(13):1-10.

16. Kumar N, Kumar D, Kumar S, et al. Spatio-temporal variations in hydro-geochemistry of groundwater at rural, urban and industrial areas of Kanpur, India. Environmental Sustainability. 2018;(1):197-208.

17. Zotou I, Tsihrintzis AV. Performance of Seven Water Quality Indices (WQIs) in a Mediterranean River. Environ Monit Assess. 2019;(191):505.

18. Akumtoshi L, Singh MR, Puro N. Assessment of water quality status of Doyang River, Nagaland, India, using Water Quality Index. Applied Water Science. 2020;10(46):13.

19. Salman J, SauadAl-Shammary A. Monitoring Lotic Ecosystem by the Application of Water Quality Index (CCMEWQI). Baghdad Science Journal. 2020;17(1):23-27.
20. Tyagi S, Sharma B, Singh P, Dobhal R. Water Quality Assessment in Terms of Water Quality Index. American Journal of Water Resources. 2013;1(3):34-38.

21. Kanga Idé S, Chikhaoui M, Naimi M. Water Quality Assessment Using a New Proposed Water Quality Index: A Case Study from Morocco. International Journal of Environment, Agriculture and Biotechnology (IJEAB). 2019;4(4).

22. Santhosh Kumar N, Venkata SubbaRao M, Phani Surya Murali KM. Water quality index method in assessing groundwater quality of Palakonda mandal in Srikakulam district, Andhra Pradesh, India. Applied Water Science. 2020;(10):30.

23. Vilane BRT, Dlamini J. An assessment of the Mhlambanyoni spring water quality at Sigombeni, Swaziland. J Agric Sci Eng. 2016;(2):40-45.

24. Naser HJ, Zanaib KH, Issa HA. Evaluating of The Gharraf River Water Thi Qar Southern Irarq Using The Water Quality Index (WQI). Journal of Education for Pure Science- University of Thi-Qar. 2019;9(2).

25. Boussaha S, Laifa A. Wadi Bounamoussa's waters quality in the northeast of Algeria: Statistical treatment of some physical and chemical parameters. Journal of Water and Land Development. 2017;(34):77-83.

26. Mebarki AApport des cours d'eau et cartographie du bilan hydrologique: cas des bassins de l'Algérie orientale. Science et changements planétaires/Sécheresse. 2010;(21):301-308.

27. Rodier J. L'analyse de l'eau [The water analysis]. eight eme éd. Dunod, Paris; 1996.

28. Motsara M, Roy RN. Guide to laboratory establishment for plant nutrient analysis, vol 19. Food and Agriculture Organization of the United Nations, Rome, 2008.

29. APHA. WPCF. Standard methods for the examination of water and wastewater. American Public Health Association, Washington, DC; 1995.

30. WHO. Guidelines for drinking-water quality. World Health Organization. 2011;(216):303-304.

31. Abbasi T, Abbasi SA. Water quality indices. Elsevier, Amsterdam. 2012.

32. Yadav AK, Khan P, Sharma SK. Water Quality Index Assessment of Groundwater in Todaraisingh Tehsil of Rajasthan State, India-A Greener Approach. Journal of Chemistry. 2010;(7):S428-S432.

33. Lescesen I, Pantelic M, Dolinaj D, et al. Statistical analysis of water quality parameters of the Drina River (West Serbia), 2004-11. Pol. J. Environ. Stud. 2015;24(2):555-561.

34. Singh K, Kamal RK. Application of Water Quality Index for Assessment of Surface Water Quality Status in Goa. Current World Environment. 2014; 9(3):994-1000.

35. Avantica C, Manish KJ, Vipin K. Quality index of surface water near overburden dumping site in Coal mining area. Mesopotamia Environmental Journal. 2014;(15):18-22.

36. Asibor G, Ofuya O. Surface Water Quality Assessment of Warri Metropolis Using Water Quality Index, International Letters of Natural Sciences. 2019;(74):18-25.

37. Alhadithi M. Evaluation of groundwater quality using water quality (WQI) and GIS techniques. Iraqi Journal of Agricultural Sciences. 2018;49(2):313-326.

38. Brown R, Mccleiland N, Deiniger R, et al. Water quality index-crossing the physical barrier. In: Proceedings of international conference on water pollution research, Jerusalem. 1972;3:787-797.

39. Ramakrishnaiah C, Sadashivaiah C, Ranganna G. Assessment of water quality index for the groundwater in Tumkur Taluk, Karnataka State, India. Journal of Chemistry. 2009;(6):523-530. 